\title{
Cerebrospinal fluid concentration of gefitinib and erlotinib in patients with non-small cell lung cancer.
}

\section{AUTHOR(S):}

Togashi, Yosuke; Masago, Katsuhiro; Masuda, Satohiro; Mizuno, Tomoyuki; Fukudo, Masahide; Ikemi, Yasuaki; Sakamori, Yuichi; ... Kim, Young Hak; Katsura, Toshiya; Mishima, Michiaki

\section{CITATION:}

Togashi, Yosuke ...[et al]. Cerebrospinal fluid concentration of gefitinib and erlotinib in patients with non-small cell lung cancer.. Cancer chemotherapy and pharmacology 2012, 70(3): 399-405

\section{ISSUE DATE:}

2012-09

URL:

http://hdl.handle.net/2433/160403

\section{RIGHT:}

The final publication is available at www.springerlink.com; この論文は 出版社版でありません。引用の際には出版社版をご確認ご利用くださ $\iota_{\circ}$; This is not the published version. Please cite only the published version. 
Title:

Cerebrospinal fluid concentration of gefitinib and erlotinib in patients with non-small cell lung cancer

Authors:

Yosuke Togashi, Katsuhiro Masago, Satohiro Masuda, Tomoyuki Mizuno, Masahide Fukudo, Yasuaki Ikemi, Yuichi Sakamori, Hiroki Nagai, Young Hak Kim, Toshiya Katsura, Michiaki Mishima

Y. Togashi, K. Masago, Y. Sakamori, H. Nagai, Y. H. Kim, M. Mishima

Department of Respiratory Medicine, Graduate School of Medicine, Kyoto University, 54

Shogoin-Kawaharacho, Sakyo-ku, Kyoto 606-8507 Japan

S. Masuda, T. Mizuno, M. Fukudo, Y. Ikemi, T. Katsura

Department of Pharmacy, Graduate School of Medicine, Kyoto University Hospital, 54

Shogoin-Kawaharacho, Sakyo-ku, Kyoto 606-8507 Japan

Financial support: S. Masuda is supported by Funding Program for Next Generation World-Leading Researchers (NEXT Program; LS073).

Conflict of interest: None declared.

\section{Corresponding author and reprint requests:}

Yosuke Togashi, M.D.

Department of Respiratory Medicine, Graduate School of Medicine, Kyoto University, 54

Shogoin-Kawaharacho, Sakyo-ku, Kyoto 606-8507 Japan

Phone: +81-75-751-3830; Fax: +81-75-751-4643

E-mail: ytogashi@kuhp.kyoto-u.ac.jp 


\begin{abstract}
Purpose Several cases have been reported in which central nervous system (CNS) metastases of non-small cell lung cancer (NSCLC) resistant to gefitinib were improved by erlotinib. However, there has been no study in which cerebrospinal fluid (CSF) concentrations of gefitinib and erlotinib are directly compared. Thus, we aimed to compare them.

Methods We examined 15 Japanese patients with NSCLC and CNS metastases with epidermal growth factor receptor gene mutations who received CSF examinations during epidermal growth factor receptor-tyrosine kinase inhibitors treatment (250 mg daily gefitinib or $150 \mathrm{mg}$ daily erlotinib). Plasma and CSF concentrations were determined using high-performance liquid chromatography with tandem mass spectrometry.

Results The concentration and penetration rate of gefitinib (mean \pm standard deviation) in the CSF were $3.7 \pm 1.9 \mathrm{ng} / \mathrm{mL}(8.2 \pm 4.3 \mathrm{nM})$ and $1.13 \pm 0.36 \%$, respectively. The concentration and penetration rate of erlotinib in the CSF were $28.7 \pm 16.8 \mathrm{ng} / \mathrm{mL}(66.9 \pm 39.0 \mathrm{nM})$ and $2.77 \pm 0.45 \%$, respectively. The CSF concentration and penetration rate of erlotinib were significantly higher than those of gefitinib $(P=$ 0.0008 and $<0.0001$, respectively). The CNS response rates of patients with erlotinib treatment were preferentially (but not significantly) higher than those with gefitinib treatment. (1/3 vs 4/7, respectively). Leptomeningeal metastases in one patient, which were refractory to gefitinib, dramatically responded to erlotinib.

Conclusions This study suggested that higher CSF concentration could be achieved with erlotinib and that erlotinib could be more effective for the treatment of CNS metastases, especially leptomeningeal metastases, than gefitinib.
\end{abstract}

Key words: non-small cell lung cancer, epidermal growth factor receptor gene mutation, gefitinib, erlotinib, cerebrospinal fluid, leptomeningeal metastases 


\section{Introduction}

Somatic activating mutations of the epidermal growth factor receptor (EGFR) gene (EGFR mutations) were first discovered in 2004 [1, 2]. Patients with non-small cell lung cancer (NSCLC) with EGFR mutations generally respond to EGFR-tyrosine kinase inhibitors (EGFR-TKIs; e.g., gefitinib and erlotinib) and achieve long-term progression-free survival (PFS) [1, 2]. Nevertheless, the majority of these patients experience eventual disease progression, despite an initial dramatic response to treatment. The CNS is a common site of recurrence, and this is thought to be due to the penetration of the agents into the CNS [3, 4]. A report described refractory CNS metastases of NSCLC that were improved by high-dose gefitinib treatment [5]. Several cases in which intermittent, high-dose erlotinib improved CNS metastases that were resistant to continuous, normal-dose erlotinib have also been reported [6-9]. These observations suggest the hypothesis that high cerebrospinal fluid (CSF) concentrations can be achieved by the high-dose administration of EGFR-TKIs. In addition, there have been several cases in which CNS metastases resistant to gefitinib were improved by erlotinib, suggesting that higher CSF concentrations can be achieved with erlotinib than with gefitinib [10]. Although some reports have shown the CSF concentration of each agent [5, 11-14], the CSF concentrations of gefitinib and erlotinib have never been directly compared. Thus, in the present study, we investigated the plasma and CSF concentrations of gefitinib and erlotinib in patients with NSCLC and CNS metastases with EGFR mutations.

\section{Patients and methods}

\section{Patients}

We examined 15 Japanese patients with NSCLC and CNS metastases with EGFR mutations who received CSF examinations during EGFR-TKI treatment (250 mg daily gefitinib or $150 \mathrm{mg}$ daily erlotinib) between April 2010 and March 2012 at Kyoto University Hospital. Two of the 15 patients received gefitinib and erlotinib treatment; therefore, we analyzed 17 plasma and 17 CSF samples from 15 patients. Before the collection of samples and analyses, we obtained written informed consent from all patients. This study was approved by the Ethics Committee of Kyoto University Graduate School and Faculty of Medicine.

\section{Sample analysis}

Blood and CSF samples were obtained just before the administration of EGFR-TKIs when their plasma concentration had achieved a steady state, that is, after day 8. Plasma and CSF concentrations of gefitinib and erlotinib were determined using high-performance liquid chromatography with tandem mass spectrometry, as previously reported [15-18]. 
EGFR mutational analysis

Formalin-fixed, paraffin-embedded tissue blocks or cytological samples were used for DNA analysis. No CNS lesions were used for DNA analysis. We adopted the peptic nucleic acid-locked nucleic acid (PNA-LNA) polymerase chain reaction (PCR) clamp method, according to the previously described protocol [19]. Briefly, PNA clamp primers inhibit the amplification of the wild-type sequence, and LNA probes are used to specifically detect mutant sequences in the presence of wild-type sequences. The synergistic effect of these primers causes the specific PCR amplification of mutant sequences. Specific PNA-LNA probe sets to each mutation were developed to cover $>95 \%$ of $E G F R$ mutations previously reported in Japan [20].

\section{Response evaluation}

Except for case 7 and 11, the response of CNS disease was assessed using magnetic resonance imaging (MRI) and the Response Evaluation Criteria in Solid Tumors (RECIST) version 1.1 [21]. However, RECIST defines leptomeningeal metastases as "nontarget" lesions, and a clear but incomplete response is designated as a "noncomplete response/nonprogressive disease" rather than either a partial response or stable disease. Thus, the patient with clearly improved leptomeningeal disease (Fig. 1A, B) was designated as a partial responder.

\section{Statistical analysis}

Continuous variables were analyzed using the t-test, and the results were expressed as the mean \pm standard deviation. Dichotomous variables were analyzed using Fisher's exact test. All analyses, performed by using JMP 8 software (SAS Institute, Cary, NC, USA), were two-tailed, and $P$-values less than 0.05 were considered statistically significant.

\section{Results}

The clinical characteristics of all patients $(n=15)$ are summarized in Table 1. Six patients received CSF examinations during gefitinib treatment (cases 1-6), 7 patients during erlotinib treatment (cases 7-13), and 2 patients during both treatments (cases 14 and 15). In addition to cases 14 and 15, case 10 received gefitinib treatment before erlotinib treatment, but he did not receive a CSF examination during gefitinib treatment. Cases 1 and 14 did not have CNS metastases before the initiation of gefitinib, but they had subsequent CNS metastases and received a CSF examination. Cases 7, 11, and 15 had leptomeningeal metastases as determined by CSF cytology.

The plasma and CSF concentrations of EGFR-TKIs are summarized in Table 2. The CSF concentration and penetration rate of gefitinib were $3.7 \pm 1.9 \mathrm{ng} / \mathrm{mL}(8.2 \pm 4.3 \mathrm{nM})$ and $1.13 \pm 0.36 \%$, respectively. 
The CSF concentration and penetration rate of erlotinib were $28.7 \pm 16.8 \mathrm{ng} / \mathrm{mL}(66.9 \pm 39.0 \mathrm{nM})$ and $2.77 \pm 0.45 \%$, respectively. The CSF concentration and penetration rate of erlotinib were significantly higher than those of gefitinib (t-test, $P=0.0008$ and $<0.0001$, respectively) (Fig. 2).

By formal RECIST evaluation, the response rate of CNS disease was 38\% (3/8). However, case 15 achieved a clear radiographic response with erlotinib treatment (Fig. 1A, B). Although case 7 could not receive the brain MRI, her symptoms, performance status (PS), and CSF cytology improved following initiation of erlotinib treatment. Although case 11 also could not receive the brain MRI, her symptoms, PS, and CSF cytology got worsened in spite of erlotinib treatment. Including these patients, there was no significant difference between gefitinib and erlotinib $(1 / 3 v s 4 / 7$, Fisher's exact, $P=1.00)$.

The leptomeningeal metastases of case 15 , which were refractory to gefitinib, dramatically responded to erlotinib (Fig. 1A, B). The CSF concentration of gefitinib was $7.2 \mathrm{nM}$ and that of erlotinib increased to $68.2 \mathrm{nM}$. His PS, which had deteriorated to 4 due to leptomeningeal metastases during gefitinib treatment, improved to 2 after the initiation of erlotinib treatment.

\section{Discussion}

This study demonstrated that the CSF concentration and penetration rate of erlotinib were significantly higher than those of gefitinib. Although these results were similar to those of previous reports [5, 11-14], to the best of our knowledge, this is the first report in which the CSF concentration and penetration rate of both agents were analyzed and directly compared.

Patients with NSCLC who have EGFR mutations generally respond to EGFR-TKIs [1, 2]. Although systemic chemotherapy for CNS metastases has been thought to play a limited role because the brain is believed to be a pharmacologic sanctuary site [22], several reports have documented the effectiveness of EGFR-TKIs in the treatment of CNS metastases of NSCLC with EGFR mutations. Although these patients dramatically respond to the treatment, the majority of them eventually undergo disease progression. The CNS is a common site of recurrence, which is thought to be due to the poor penetration of the agents into the CNS [3, 4]. Therefore, considering the higher CSF concentration of erlotinib, patients may achieve longer PFS with erlotinib treatment than with gefitinib treatment. Indeed, one pooled analysis showed such results [23].

Gefitinib and erlotinib are similar anilinoquinazoline compounds. Although it seems that erlotinib has a slightly broader spectrum of kinase inhibition than gefitinib [24], they are essentially

EGFR-specific TKIs. The most prominent difference between these two drugs is the dose setting. The approved daily dose of erlotinib (150 mg) is equal to the maximum tolerated dose (MTD) of erlotinib. In contrast, the daily dose of gefitinib was set at $250 \mathrm{mg}$, approximately one-third of the MTD of gefitinib [25-28]. This difference seemed to have a great influence on our results. In addition, there seems to be differences in the penetration rates of gefitinib and erlotinib. A major protein constituent of the blood 
brain barrier (BBB) is P-glycoprotein (P-gp), which pumps chemotherapy drugs and toxins out of the CNS $[29,30]$. The penetration differences of gefitinib and erlotinib may be dependent on their affinity for P-gp.

The CNS response rates of patients with erlotinib treatment were preferentially (but not significantly) higher than those with gefitinib treatment. But this result is debatable because the number of patients examined was very small and there were several differences in their backgrounds. In fact, the CNS metastases of case 2 responded to gefitinib even though its CSF concentration was lower than its median inhibitory concentration [31]. Several studies have suggested that chemotherapeutic agents can reach parenchymal brain metastases [32,33]. The observed contrast enhancement of parenchymal brain metastases on computed tomography and MRI also suggests that the BBB is at least partially disrupted in such patients [34]. In addition, a recent report demonstrated that $\left[{ }^{11} \mathrm{C}\right]$-erlotinib positron emission tomography showed accumulation in parenchymal brain metastases [35]. In contrast, leptomeningeal metastases can be distinguished from parenchymal brain metastases since they are associated with the spread of malignant cells throughout the subarachnoid space [36, 37]. Some cases have been reported in which leptomeningeal metastases refractory to gefitinib responded to erlotinib, as observed in case 15 [10]. In this case, an approximately 10 times higher CSF concentration of erlotinib (68.2 nM) was achieved than with gefitinib $(7.2 \mathrm{nM})$. Therefore, erlotinib can be more effective for leptomeningeal metastases than gefitinib due to its higher CSF concentration.

Patients with leptomeningeal metastases have a reduced PS and very poor prognosis [36, 37]. While most clinicians evaluate CSF cytology together with MRI and clinical examinations, underdiagnosis is a major problem [36, 37]. Therefore, even if a definite diagnosis is not made, considering the CSF concentration, erlotinib should be administered prior to gefitinib when patients are suspected of having leptomeningeal metastases.

In conclusion, the CSF concentration and penetration rate of erlotinib are higher than those of gefitinib, which supports the view that patients can achieve longer PFS with erlotinib treatment than with gefitinib and that erlotinib can be more effective for the treatment of CNS metastases, especially leptomeningeal metastases, than gefitinib. However, it is debatable whether erlotinib is more effective for parenchymal brain metastases than gefitinib. In order to confirm these findings, large prospective studies should be performed.

\section{Acknowledgments}

This research was partially supported by Funding Program for Next Generation World-Leading Researchers (NEXT Program; LS073).

\section{Conflict of interest}


The authors have no conflict of interest. 


\section{References}

1. Paez JG, Jänne PA, Lee JC, Tracy S, Greulich H, Gabriel S, Herman P, Kaye FJ, Lindeman N, Boggon TJ, Naoki K, Sasaki H, Fujii Y, Eck MJ, Sellers WR, Johnson BE, Meyerson M (2004) EGFR mutations in lung cancer: correlation with clinical response to gefitinib therapy. Science 304:1497-1500.

2. Lynch TJ, Bell DW, Sordella R, Gurubhagavatula S, Okimoto RA, Brannigan BW, Harris PL, Haserlat SM, Supko JG, Haluska FG, Louis DN, Christiani DC, Settleman J, Haber DA (2004) Activating mutations in the epidermal growth factor receptor underlying responsiveness of non-small-cell lung cancer to gefitinib. N Engl J Med 350:2129-2139.

3. Omuro AM, Kris MG, Miller VA, Franceschi E, Shah N, Milton DT, Abrey LE (2005) High incidence of disease recurrence in the brain and leptomeninges in patients with nonsmall cell lung carcinoma after response to gefitinib. Cancer 103:2344-2348.

4. Lee YJ, Choi HJ, Kim SK, Chang J, Moon JW, Park IK, Kim JH, Cho BC (2010) Frequent central nervous system failure after clinical benefit with epidermal growth factor receptor tyrosine kinase inhibitors in Korean patients with nonsmall-cell lung cancer. Cancer 116:1336-1343.

5. Jackman DM, Holmes AJ, Lindeman N, Wen PY, Kesari S, Borras AM, Bailey C, de Jong F, Janne PA, Johnson BE (2006) Response and resistance in a non-small-cell lung cancer patient with an epidermal growth factor receptor mutation and leptomeningeal metastases treated with high-dose gefitinib. J Clin Oncol 24:4517-4520.

6. Dhruva N, Socinski MA (2009) Carcinomatous meningitis in non-small-cell lung cancer: response to high-dose erlotinib. J Clin Oncol 27:31-32.

7. Clarke JL, Pao W, Wu N, Miller VA, Lassman AB (2010) High dose weekly erlotinib achieves therapeutic concentrations in CSF and is effective in leptomeningeal metastases from epidermal growth factor receptor mutant lung cancer. J Neurooncol 99:283-286.

8. Hata A, Kaji R, Fujita S, Katakami N (2011) High-dose erlotinib for refractory brain metastases in a patient with relapsed non-small cell lung cancer. J Thorac Oncol 6:653-654.

9. Grommes C, Oxnard GR, Kris MG, Miller VA, Pao W, Holodny AI, Clarke JL, Lassman AB (2011) "Pulsatile" high-dose weekly erlotinib for CNS metastases from EGFR mutant non-small cell lung cancer. Neuro Oncol 13:1364-1369.

10. Katayama T, Shimizu J, Suda K, Onozato R, Fukui T, Ito S, Hatooka S, Sueda T, Hida T, Yatabe Y, Mitsudomi T (2009) Efficacy of erlotinib for brain and leptomeningeal metastases in patients with lung adenocarcinoma who showed initial good response to gefitinib. J Thorac Oncol 4:1415-1419.

11. Fukuhara T, Saijo Y, Sakakibara T, Inoue A, Morikawa N, Kanamori M, Nakashima I, Nukiwa T (2008) Successful treatment of carcinomatous meningitis with gefitinib in a patient with lung adenocarcinoma harboring a mutated EGF receptor gene. Tohoku J Exp Med 214:359-363. 
12. Togashi Y, Masago K, Fukudo M, Terada, T, Fujita S, Irisa K, Sakamori Y, Kim YH, Mio T, Inui K, Mishima M (2010) Cerebrospinal fluid concentration of erlotinib and its active metabolite OSI-420 in patients with central nervous system metastases of non-small cell lung cancer. J Thorac Oncol 5:950-955.

13. Masuda T, Hattori N, Hamada A, Iwamoto H, Ohshimo S, Kanehara M, Ishikawa N, Fujitaka K, Haruta Y, Murai H, Kohno, N (2011) Erlotinib efficacy and cerebrospinal fluid concentration in patients with lung adenocarcinoma developing leptomeningeal metastases during gefitinib therapy. Cancer Chemother Pharmacol 67:1465-1469.

14. Togashi Y, Masago K, Fukudo M, Tsuchido Y, Okuda C, Kim YH, Ikemi Y, Sakamori Y, Mio T, Katsura T, Mishima M (2011) Efficacy of increased-dose erlotinib for central nervous system metastases in non-small cell lung cancer patients with epidermal growth factor receptor mutation. Cancer Chemother Pharmacol 68:1089-1092.

15. Jones HK, Stafford LE, Swaisland HC, Payne R (2002) A sensitive assay for ZD1839 (Iressa) in human plasma by liquid-liquid extraction and high performance liquid chromatography with mass spectrometric detection: validation and use in Phase I clinical trials. J Pharm Biomed Anal 29:221-228.

16. Zhao M, Hartke C, Jimeno A, Li J, He P, Zabelina Y, Hidalgo M, Baker SD (2005) Specific method for determination of gefitinib in human plasma, mouse plasma and tissues using high performance liquid chromatography coupled to tandem mass spectrometry. J Chromatogr B Analyt Technol Biomed Life Sci 819:73-80.

17. Zhao M, He P, Rudek MA, Hidalgo M, Baker SD (2003) Specific method for determination of OSI-774 and its metabolite OSI-420 in human plasma by using liquid chromatography-tandem mass spectrometry. J Chromatogr B Analyt Technol Biomed Life Sci 793:413-420.

18. Masters AR, Sweeney CJ, Jones DR (2007) The quantification of erlotinib (OSI-774) and OSI-420 in human plasma by liquid chromatography-tandem mass spectrometry. J Chromatogr B Analyt Technol Biomed Life Sci 848:379-383.

19. Nagai Y, Miyazawa H, Huqun, Tanaka T, Udagawa K, Kato M, Fukuyama S, Yokote A, Kobayashi K, Kanazawa M, Hagiwara K (2005) Genetic heterogeneity of the epidermal growth factor receptor in non-small cell lung cancer cell lines revealed by a rapid and sensitive detection system, the peptide nucleic acid-locked nucleic acid PCR clamp. Cancer Res 65:7276-7282.

20. Kosaka T, Yatabe Y, Endoh H, Kuwano H, Takahashi T, Mitsudomi T (2004) Mutations of the epidermal growth factor receptor gene in lung cancer: biological and clinical implications. Cancer Res 64:8919-8923.

21. Eisenhauer EA, Therasse P, Bogaerts J, Schwartz LH, Sargent D, Ford R, Dancey J, Arbuck S, Gwyther S, Mooney M, Rubinstein L, Shankar L, Dodd L, Kaplan R, Lacombe D, Verweij J (2009) New response evaluation criteria in solid tumours: revised RECIST guideline (version 1.1). Eur J 
Cancer 45:228-247.

22. Langer CJ, Mehta MP (2005) Current management of brain metastases, with a focus on systemic options. J Clin Oncol 23:6207-6219.

23. Paz-Ares L, Soulières D, Melezínek I, Moecks J, Keil L, Mok T, Rosell R, Klughammer B (2010) Clinical outcomes in non-small-cell lung cancer patients with EGFR mutations: pooled analysis. J Cell Mol Med 14:51-69.

24. Fabian MA, Biggs WH $3^{\text {rd }}$, Treiber DK, Atteridge CE, Azimioara MD, Benedetti MG, Carter TA, Ciceri P, Edeen PT, Floyd M, Ford JM, Galvin M, Gerlach JL, Grotzfeld RM, Herrgard S, Insko DE, Insko MA, Lai AG, Lelias JM, Mehta SA, Milanov ZV, Velasco AM, Wodicka LM, Patel HK, Zarrinkar PP, Lockhart DJ (2005) A small molecule-kinase interaction map for clinical kinase inhibitors. Nat Biotechnol 23:329-336.

25. Nakagawa K, Tamura T, Negoro S, Kudoh S, Yamamoto N, Takeda K, Swaisland H, Nakatani I, Hirose M, Dong RP, Fukuoka, M (2003) Phase I pharmacokinetic trial of the selective oral epidermal growth factor receptor tyrosine kinase inhibitor gefitinib ('Iressa', ZD1839) in Japanese patients with solid malignant tumors. Ann Oncol 14:922-930.

26. Cohen MH, Williams GA, Sridhara R, Chen G, Pazdur R (2003) FDA drug approval summary: gefitinib (ZD1839) (Iressa) tablets. Oncologist 8:303-306.

27. Yamamoto N, Horiike A, Fujisaka Y, Murakami H, Shimoyama T, Yamada Y, Tamura T (2008) Phase I dose-finding and pharmacokinetic study of the oral epidermal growth factor receptor tyrosine kinase inhibitor Ro50-8231 (erlotinib) in Japanese patients with solid tumors. Cancer Chemother Pharmacol 61:489-496.

28. Cohen MH, Johnson JR, Chen YF, Sridhara R, Pazdur R (2005) FDA drug approval summary: erlotinib (Tarceva) tablets. Oncologist 10:461-466.

29. Gerstner ER, Fine RL (2007) Increased permeability of the blood-brain barrier to chemotherapy in metastatic brain tumors: establishing a treatment paradigm. J Clin Oncol 25:2306-2312.

30. Elmeliegy MA, Carcaboso AM, Tagen M, Bai F, Stewart CF (2011) Role of ATP-binding cassette and solute carrier transporters in erlotinib CNS penetration and intracellular accumulation. Clin Cancer Res 17:89-99.

31. Mukohara T, Engelman JA, Hanna NH, Yeap BY, Kobayashi S, Lindeman N, Halmos B, Pearlberg J, Tsuchihashi Z, Cantley LC, Tenen DG, Johnson BE, Janne PA (2005) Differential effects of gefitinib and cetuximab on non-small-cell lung cancers bearing epidermal growth factor receptor mutations. J Natl Cancer Inst 97:1185-1194.

32. Zhang RD, Price JE, Fujimaki T, Bucana CD, Fidler IJ (1992) Differential permeability of the blood-brain barrier in experimental brain metastases produced by human neoplasms implanted into nude mice. Am J Pathol 141:1115-1124. 
33. Stewart DJ (1994) A critique of the role of the blood-brain barrier in the chemotherapy of human brain tumors. J Neurooncol 20:121-139.

34. Davey P (2002) Brain metastases: treatment options to improve outcomes. CNS Drugs 16:325-338.

35. Weber B, Winterdahl M, Memon A, Sorensen BS, Keiding S, Sorensen L, Nexo E, Meldgaard P (2011) Erlotinib accumulation in brain metastases from non-small cell lung cancer: visualization by positron emission tomography in a patient harboring a mutation in the epidermal growth factor receptor. J Thorac Oncol 6:1287-1289.

36. Gleissner B, Chamberlain MC (2006) Neoplastic meningitis. Lancet Neurol 5:443-452.

37. Lombardi G, Zustovich F, Farina P, Della Puppa A, Manara R, Cecchin D, Brunello A, Cappetta A, Zagonel V (2011) Neoplastic Meningitis from Solid Tumors: New Diagnostic and Therapeutic Approaches. Oncologist 16:1175-1188. 


\section{Figure captions}

Fig. 1 Brain magnetic resonance imaging (MRI) of case 15. a Contrast (gadolinium)-enhanced coronal T1 MRI during gefitinib treatment demonstrated leptomeningeal metastases (arrowheads). His performance status (PS) had deteriorated to 4. b Two weeks after the initiation of erlotinib treatment, the leptomeningeal metastases had improved, and his PS also improved to 2.

Fig. 2 Cerebrospinal fluid (CSF) concentrations (a) and penetration rates (b) with interquartile ranges. The CSF concentration and penetration rate of erlotinib were significantly higher than those of gefitinib $(66.9 \pm 39.0$ vs $8.2 \pm 4.3 \mathrm{nM}$, t-test, $P=0.0008$ and $2.77 \pm 0.45$ vs $1.13 \pm 0.36 \%$, t-test, $P<0.0001$, respectively). 
Figure 1

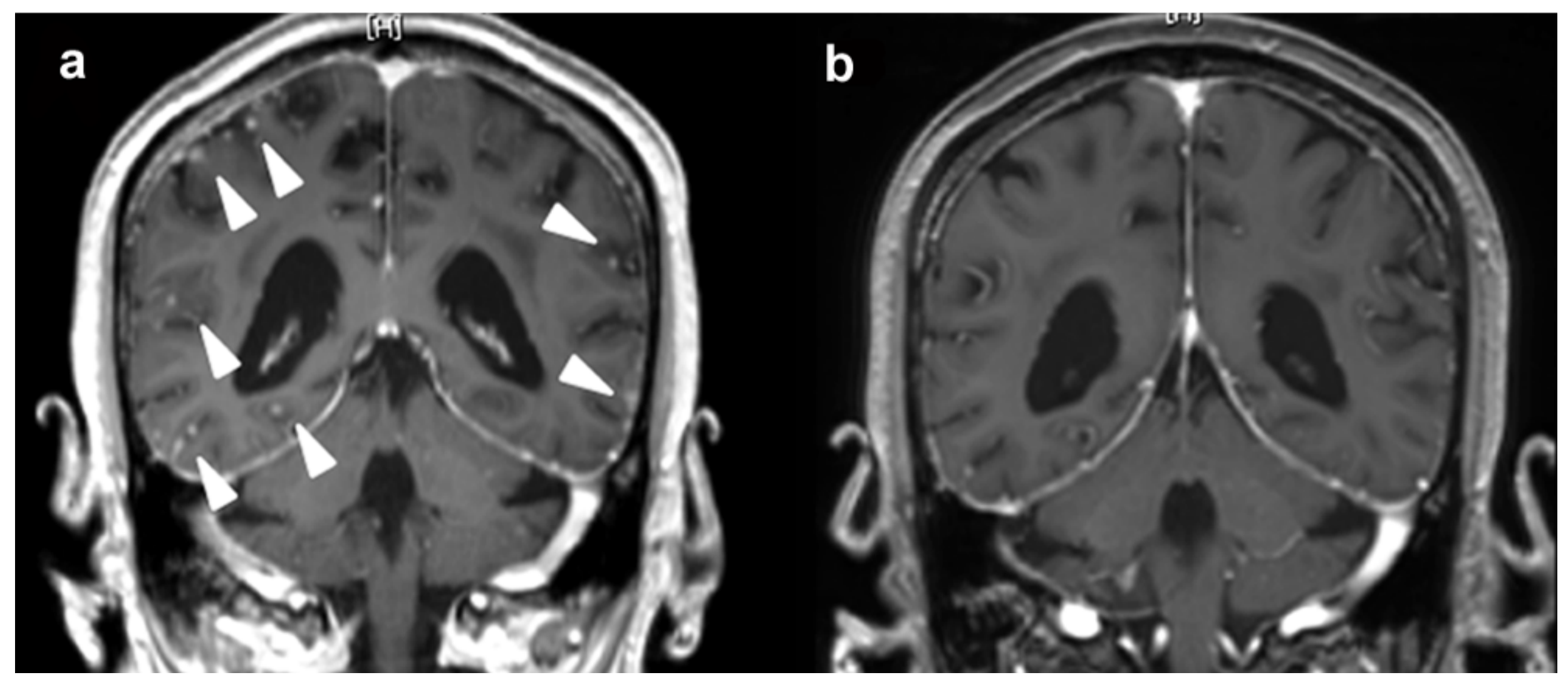


Figure 2

a

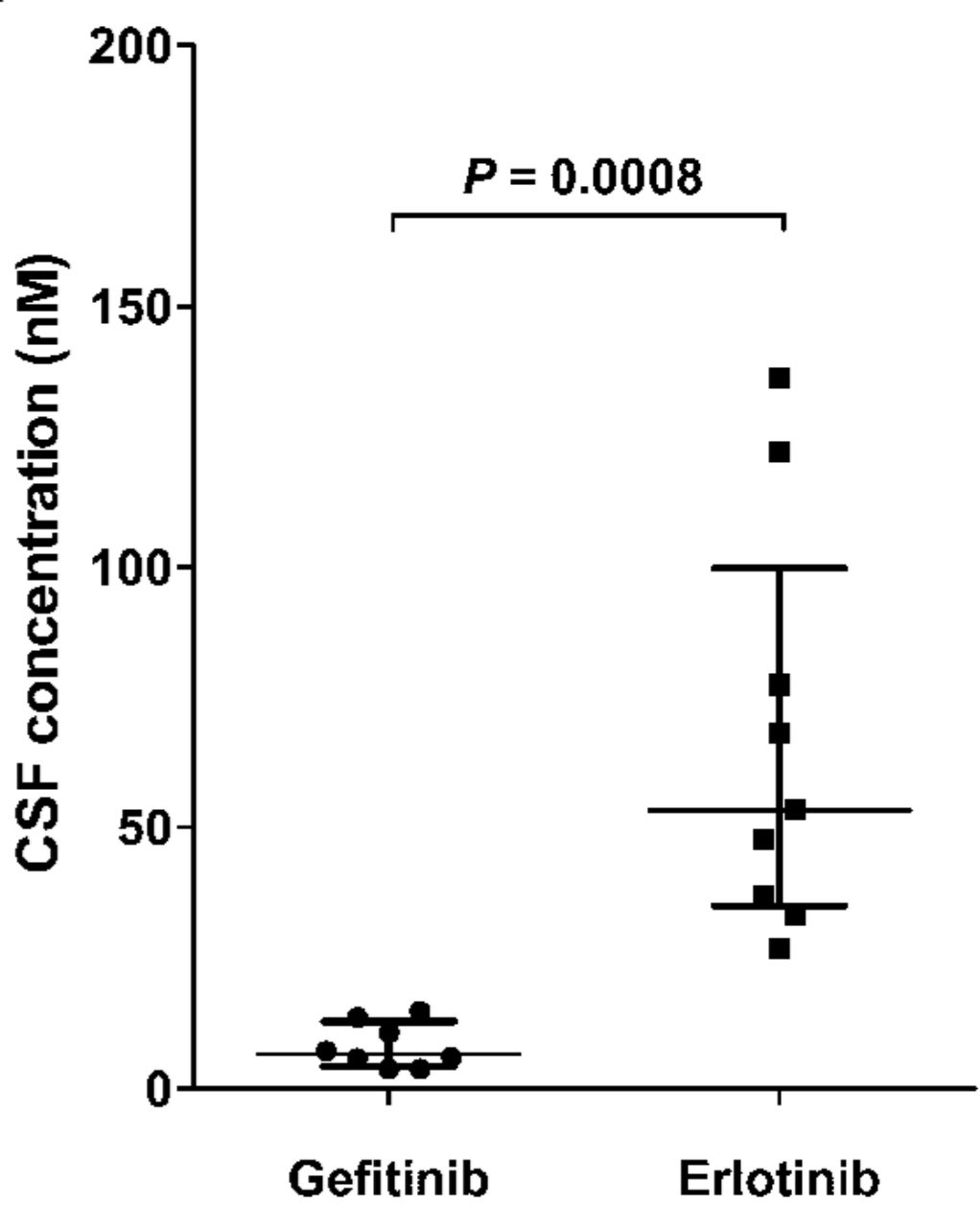

b

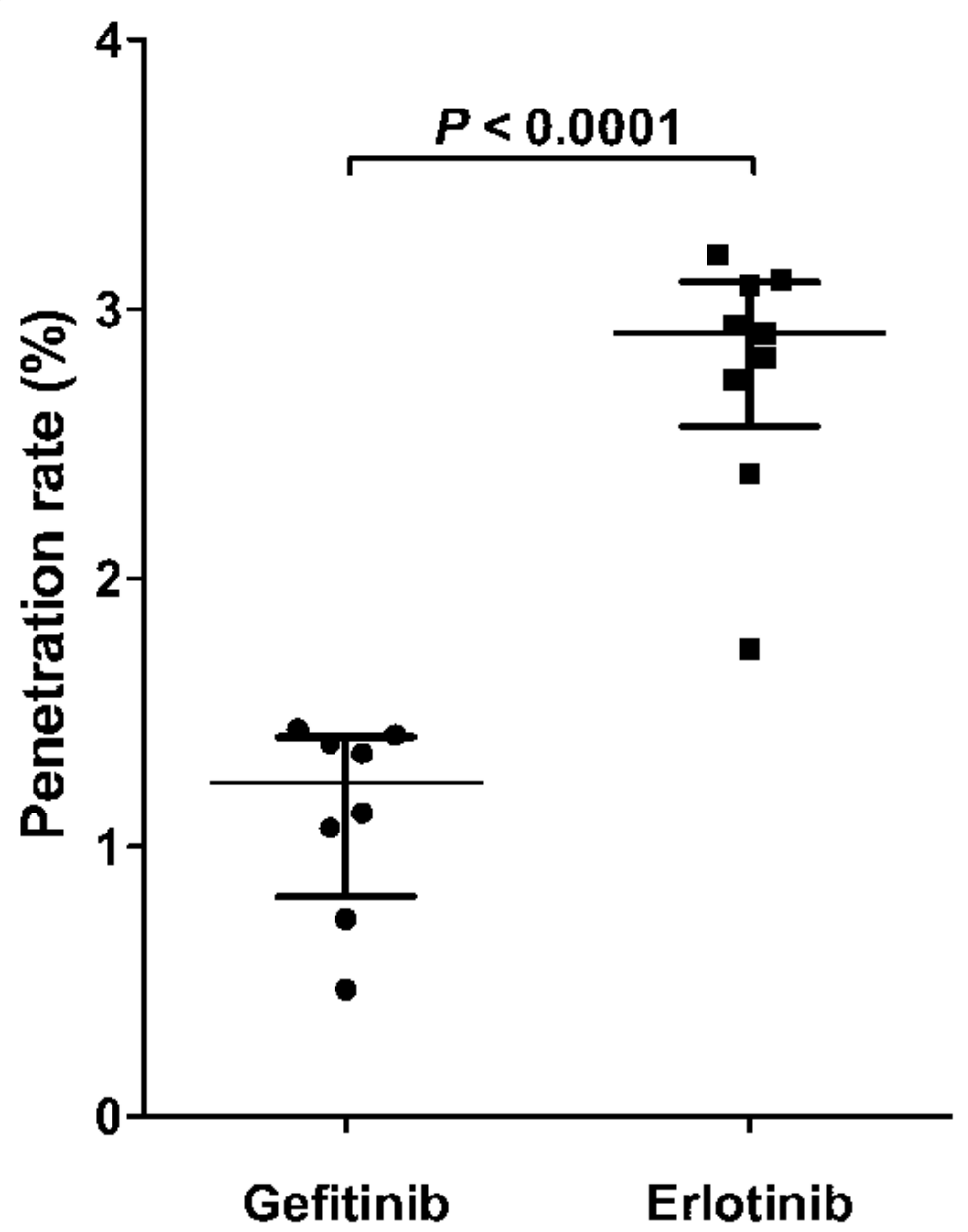


Table 1. Patient characteristics

\begin{tabular}{|c|c|c|c|c|c|c|c|c|c|c|c|}
\hline Case & Age (yr) & Sex & PS & Histology & EGFR & $\begin{array}{l}\text { Smoking } \\
\text { status }\end{array}$ & CSF cytology & EGFR-TKI & $\begin{array}{l}\text { Previous } \\
\text { CTx }\end{array}$ & $\begin{array}{l}\text { Previous EGFR-TKI } \\
\text { (length of PFS) }\end{array}$ & $\begin{array}{c}\text { Previous } \\
\text { WBRT }\end{array}$ \\
\hline 1 & 74 & $\mathrm{~F}$ & 0 & NSCLC & Ex 21; L858R & Never & Negative & Gefitinib & 1 & No & Yes \\
\hline 2 & 56 & $\mathrm{~F}$ & 3 & Ad & Ex 19 deletion & Never & Negative & Gefitinib & 0 & No & Yes \\
\hline 3 & 74 & $\mathrm{~F}$ & 2 & Ad & Ex 19 deletion & Never & Negative & Gefitinib & 1 & No & No \\
\hline 4 & 56 & M & 1 & Ad & Ex 19 deletion & Never & Negative & Gefitinib & 1 & No & No \\
\hline 5 & 62 & $\mathrm{~F}$ & 3 & Ad & Ex 21; L858R & Never & Negative & Gefitinib & 0 & No & No \\
\hline 6 & 74 & $\mathrm{~F}$ & 1 & Ad & Ex 19 deletion & Never & Negative & Gefitinib & 0 & No & Yes \\
\hline 7 & 39 & $\mathrm{~F}$ & 3 & Ad & Ex 19 deletion & Never & Positive & Erlotinib & 5 & Erlotinib (16.4 months) & Yes \\
\hline 8 & 69 & $\mathrm{~F}$ & 2 & Ad & Ex 19 deletion & Never & Negative & Erlotinib & 0 & No & Yes \\
\hline 9 & 55 & M & 1 & Ad & Ex 19 deletion & Former & Negative & Erlotinib & 0 & No & No \\
\hline 10 & 51 & M & 1 & Ad & Ex 19 deletion & Former & Negative & Erlotinib & 5 & Gefitinib (16.9 months) & No \\
\hline 11 & 61 & $\mathrm{~F}$ & 3 & Ad & Ex 21; L858R & Never & Positive & Erlotinib & 1 & No & No \\
\hline 12 & 65 & $\mathrm{~F}$ & 0 & NSCLC & Ex 19 deletion & Never & Negative & Erlotinib & 1 & No & No \\
\hline 13 & 77 & $\mathrm{~F}$ & 2 & Ad & Ex 19 deletion & Never & Negative & Erlotinib & 1 & No & No \\
\hline \multirow{2}{*}{14} & 76 & M & 1 & Ad & Ex 19 deletion & Former & Negative & Gefitinib & 1 & No & No \\
\hline & 76 & M & 2 & Ad & Ex 19 deletion & Former & Negative & Erlotinib & 2 & Gefitinib (6.4 months) & Yes \\
\hline \multirow{2}{*}{15} & 69 & M & 2 & Ad & Ex 21; L858R & Former & Positive & Gefitinib & 1 & No & No \\
\hline & 69 & M & 4 & Ad & Ex 21; L858R & Former & Positive & Erlotinib & 2 & Gefitinib (1.6 months) & Yes \\
\hline
\end{tabular}

Ad adenocarcinoma, CSF cerebrospinal fluid, CTx, chemotherapy, EGFR epidermal growth factor receptor gene, EGFR-TKI epidermal growth factor receptor-tyrosine kinase inhibitor, Ex exon, $F$ female, Former former smoker, $M$ male, NE not evaluated, Never never smoked, NSCLC non-small cell lung cancer, 
PFS progression-free survival, PS performance status, WBRT whole-brain radiotherapy 
Table 2. Plasma and cerebrospinal fluid concentrations and response of the central nervous system metastases

\begin{tabular}{|c|c|c|c|c|c|}
\hline EGFR-TKI & Case & Plasma concentration & CSF concentration & Penetration rate & CNS response \\
\hline \multirow{9}{*}{ Gefitinib } & 1 & 234 ng/ml (524 nM) & $1.7 \mathrm{ng} / \mathrm{ml}(3.8 \mathrm{nM})$ & $0.73 \%$ & \\
\hline & 2 & 364 ng/ml (814 nM) & $1.7 \mathrm{ng} / \mathrm{ml}(3.8 \mathrm{nM})$ & $0.47 \%$ & Partial response \\
\hline & 3 & 452 ng/ml (1011 nM) & $4.8 \mathrm{ng} / \mathrm{ml}(10.7 \mathrm{nM})$ & $1.07 \%$ & NE \\
\hline & 4 & 430 ng/ml (962 nM) & $6.1 \mathrm{ng} / \mathrm{ml}(13.6 \mathrm{nM})$ & $1.42 \%$ & NE \\
\hline & 5 & 238 ng/ml (533 nM) & $2.7 \mathrm{ng} / \mathrm{ml}(6.0 \mathrm{nM})$ & $1.13 \%$ & Stable disease \\
\hline & 6 & 181 ng/ml (405 nM) & $2.6 \mathrm{ng} / \mathrm{ml}(5.8 \mathrm{nM})$ & $1.44 \%$ & NE \\
\hline & 14 & 471 ng/ml (1054 nM) & $6.6 \mathrm{ng} / \mathrm{ml}(14.8 \mathrm{nM})$ & $1.39 \%$ & \\
\hline & 15 & 235 ng/ml (526 nM) & $3.2 \mathrm{ng} / \mathrm{ml}(7.2 \mathrm{nM})$ & $1.35 \%$ & Stable disease \\
\hline & Mean \pm SD & $326 \pm 116 \mathrm{ng} / \mathrm{ml}(729 \pm 260 \mathrm{nM})$ & $3.7 \pm 1.9 \mathrm{ng} / \mathrm{ml}(8.2 \pm 4.3 \mathrm{nM})$ & $1.13 \pm 0.36 \%$ & $1 / 3$ \\
\hline \multirow{10}{*}{ Erlotinib } & 7 & 716 ng/ml (1666 nM) & 22.9 ng/ml (53.3 nM) & $3.20 \%$ & Partial response $^{\text {a }}$ \\
\hline & 8 & 463 ng/ml (1077 nM) & 14.3 ng/ml (33.3 nM) & $3.09 \%$ & Partial response \\
\hline & 9 & 1134 ng/ml (2638 nM) & 33.3 ng/ml (77.5 nM) & $2.94 \%$ & $\mathrm{NE}$ \\
\hline & 10 & 508 ng/ml (1182 nM) & $15.8 \mathrm{ng} / \mathrm{ml}(36.8 \mathrm{nM})$ & $3.11 \%$ & Stable disease \\
\hline & 11 & 3361 ng/ml (7818 nM) & $58.6 \mathrm{ng} / \mathrm{ml}(136.3 \mathrm{nM})$ & $1.74 \%$ & Progressive disease ${ }^{b}$ \\
\hline & 12 & 482 ng/ml (1121 nM) & $11.5 \mathrm{ng} / \mathrm{ml}(26.8 \mathrm{nM})$ & $2.39 \%$ & Partial response \\
\hline & 13 & 1802 ng/ml (4192 nM) & $52.5 \mathrm{ng} / \mathrm{ml}(122.1 \mathrm{nM})$ & $2.91 \%$ & $\mathrm{NE}$ \\
\hline & 14 & 728 ng/ml (1693 nM) & $20.5 \mathrm{ng} / \mathrm{ml}(47.7 \mathrm{nM})$ & $2.82 \%$ & Progressive disease \\
\hline & 15 & 1069 ng/ml (2487 nM) & $29.3 \mathrm{ng} / \mathrm{ml}$ (68.2 nM) & $2.74 \%$ & Partial response ${ }^{c}$ \\
\hline & Mean \pm SD & $1140 \pm 937 \mathrm{ng} / \mathrm{ml}(2652 \pm 2178 \mathrm{nM})$ & $28.7 \pm 16.8 \mathrm{ng} / \mathrm{ml}(66.9 \pm 39.0 \mathrm{nM})$ & $2.77 \pm 0.45 \%$ & $4 / 7$ \\
\hline
\end{tabular}


CNS central nervous system, CSF cerebrospinal fluid, EGFR-TKI epidermal growth factor receptor-tyrosine kinase inhibitor, NE not evaluated, SD standard deviation

${ }^{a}$ Although case 7 could not receive the brain magnetic resonance imaging (MRI), her symptoms, performance status (PS), and CSF cytology improved following initiation of erlotinib treatment.

${ }^{\mathrm{b}}$ Although case 11 could not receive the brain MRI, her symptoms, PS, and CSF cytology got worsened in spite of erlotinib treatment.

${ }^{c}$ Case 15 had clear response of leptomeningeal metastases with erlotinib treatment, designated by RECIST as noncomplete response/nonprogressive disease. 